\title{
Assessment of Undiscovered Continuous Oil and Gas Resources in the Heath Formation, Central Montana and Western North Dakota, 2016
}

Using a geology-based assessment methodology, the U.S. Geological Survey estimated undiscovered, technically recoverable mean resources of 884 million barrels of oil and 106 billion cubic feet of gas in the North-Central Montana and Williston Basin Provinces of central Montana and western North Dakota.

\section{Introduction}

The U.S. Geological Survey (USGS) completed a geologybased assessment of the continuous (unconventional) oil and gas resources in the Big Snowy Trough area of central Montana and western North Dakota (fig. 1). The Big Snowy Trough was an east-west depression during Meramec time, and the north and south boundaries of the trough were later enhanced by faulting and erosion (Maughan and Roberts, 1967). The Heath Formation of the Big Snowy Group is confined to the Big Snowy Trough. This assessment is based on the geologic concepts and criteria of a total petroleum system (TPS) and includes information on the hydrocarbon source rocks, reservoir rocks, and hydrocarbon traps. In this study, we defined the Heath TPS and two assessment units (AUs) that contain similar structural, stratigraphic, and petroleum-charge histories. The assessment input data for each AU are shown in table 1.

\section{Total Petroleum System}

The Heath TPS is limited to the Heath Formation, which consists of a heterogeneous mix of lithologies that includes black shales, limestone, sandstone, anhydrite, and coal. The primary petroleum source rock is the Cox Ranch shale member in the middle of the Heath Formation. The Heath TPS is self-sourced with total organic carbon ranging from 0.5 to 26 weight percent and averaging 9 weight percent (McClave, 2012). Additional minor sources of petroleum may include the less organic-rich shale units in the upper and lower Heath Formation. Evidence suggests that some petroleum has migrated from the Heath Formation, and much of it has been produced from the overlying Tyler Formation; however, the primary resource potential is within the Heath Formation.

\section{Assessment Units}

Two AUs are identified in this assessment: the North-Central Montana Heath Continuous Oil AU and the Williston Heath Continuous Oil AU. The North-Central Montana Heath Continuous Oil AU lies within the Big Snowy Trough of central and eastern Montana and covers a maximum area of 5,255,000 acres (fig. 1). The potential resource AUs include the areas where the Heath Formation is thermally mature and not near the surface. Oil has been produced from the Heath Formation since 1919 when it was discovered in the Devil's Basin oil field on the Central Montana Uplift (IHS Markit ${ }^{\mathrm{TM}}$, 2016). The Heath Formation is the source

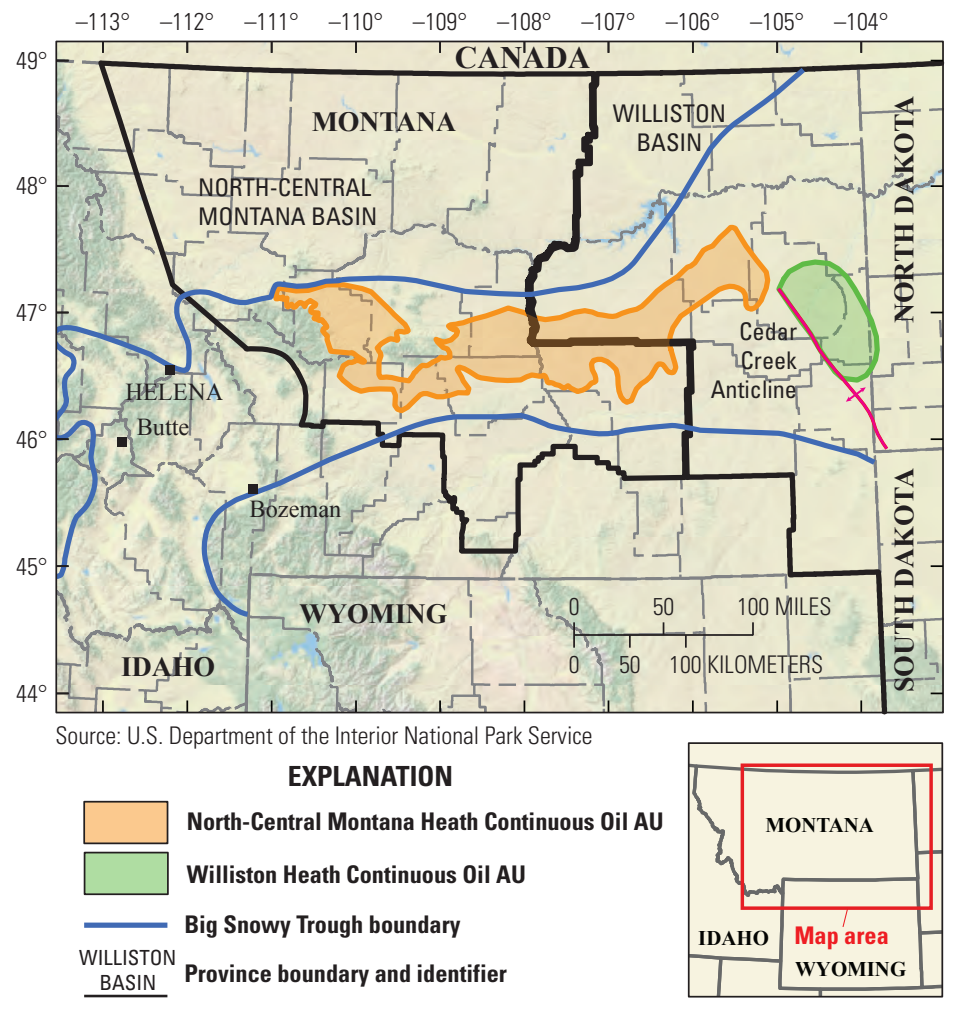

Figure 1. Location of the North-Central Montana and Williston Basin Provinces with continuous assessment unit (AU) boundaries. Cedar Creek Structure modified from Maughan (1966) and Gaswirth and others (2013). Big Snowy Trough outline modified from Derkey and others (1985).

of more than 95 million barrels of oil (MMBO) produced from the overlying Tyler Formation (Bottjer, 2014).

The Williston Heath Continuous Oil AU is along the eastern side of the Cedar Creek anticlinal structure in the southwestern portion of the Williston Basin (fig. 1). The Heath Formation is present only in a limited area (Maughan, 1966; Clement, 1986) and is thickest along the Cedar Creek anticline (greater than 300 feet according to Clement, 1986). The Heath Formation eroded during the Early Pennsylvanian on the west side of the Cedar Creek structure and only extends a short distance east from the structure (Maughan, 1966). 


\section{Undiscovered Resources Summary}

Using the USGS continuous resource methodology for assessing petroleum resources (Charpentier and Cook, 2011), we quantitatively assessed oil and gas resources in two continuous (unconventional) AUs in the North-Central Montana and Williston Basin Provinces (table 2). The overall total mean resources in the Heath Formation AUs are 884 million barrels of oil (MMBO) with an F95-F5 range from 154 MMBO to $1,965 \mathrm{MMBO}$ and 106 billion cubic feet of gas (BCFG) with an F95-F5 range from 17 BCFG to 246 BCFG.

Table 1. Key assessment input data for two continuous assessment units in the Heath Formation, Montana and North Dakota.

[AU, assessment unit; \%, percent; EUR, estimated ultimate recovery per well; MMBO, million barrels of oil. EUR, well drainage area, and success ratios are partly from U.S. shale-oil analogs. The average EUR input is the minimum, median, maximum, and calculated mean. Shading indicates not applicable]

\begin{tabular}{|c|c|c|c|c|c|c|c|c|}
\hline \multirow[b]{2}{*}{ Assessment input data } & \multicolumn{4}{|c|}{ North-Central Montana Heath Continuous Oil AU } & \multicolumn{4}{|c|}{ Williston Heath Continuous Oil AU } \\
\hline & Minimum & Mode & Maximum & $\begin{array}{l}\text { Calculated } \\
\text { mean }\end{array}$ & Minimum & Mode & Maximum & $\begin{array}{l}\text { Calculated } \\
\text { mean }\end{array}$ \\
\hline Potential production area of AU (acres) & 1,200 & $1,437,000$ & $5,255,000$ & $2,231,067$ & 600 & $1,309,000$ & $2,600,000$ & $1,303,200$ \\
\hline Average drainage area of wells (acres) & 60 & 120 & 180 & 120 & 60 & 120 & 180 & 120 \\
\hline Success ratios $(\%)$ & 40 & 70 & 80 & 63.3 & 10 & 40 & 90 & 46.7 \\
\hline Average EUR (MMBO, oil) & 0.02 & 0.05 & 0.12 & 0.053 & 0.02 & 0.05 & 0.12 & 0.053 \\
\hline AU probability & 1.0 & & & & 0.9 & & & \\
\hline
\end{tabular}

Table 2. Assessment results for two continuous assessment units in the Heath Formation, Montana and North Dakota.

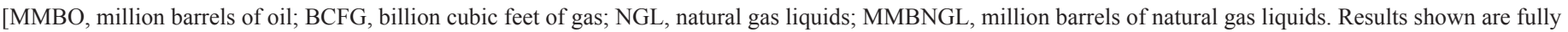

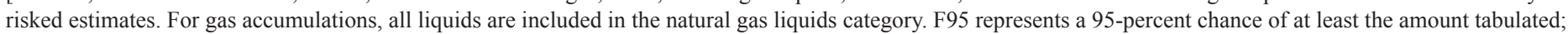
other fractiles are defined similarly. Fractiles are additive under the assumption of perfect positive correlation. Shading indicates not applicable]

\begin{tabular}{|c|c|c|c|c|c|c|c|c|c|c|c|c|c|c|}
\hline \multirow{3}{*}{$\begin{array}{l}\text { Total petroleum system and } \\
\text { assessment units (AUs) }\end{array}$} & \multirow{3}{*}{$\underset{\text { probability }}{\mathrm{AU}}$} & \multirow{3}{*}{$\begin{array}{l}\text { Accumulation } \\
\text { type }\end{array}$} & \multicolumn{12}{|c|}{ Total undiscovered resources } \\
\hline & & & \multicolumn{4}{|c|}{ Oil (MMBO) } & \multicolumn{4}{|c|}{ Gas (BCFG) } & \multicolumn{4}{|c|}{ NGL (MMBNGL) } \\
\hline & & & F95 & $\mathrm{F} 50$ & F5 & Mean & F95 & $\mathrm{F} 50$ & F5 & Mean & F95 & F50 & $\mathrm{F} 5$ & Mean \\
\hline \multicolumn{15}{|c|}{ Heath Total Petroleum System } \\
\hline $\begin{array}{l}\text { North-Central Montana Heath Continuous } \\
\text { Oil AU }\end{array}$ & 1.0 & Oil & 154 & 563 & 1,371 & 637 & 17 & 66 & 172 & 76 & 0 & 0 & 1 & 0 \\
\hline Williston Heath Continuous Oil AU & 0.9 & Oil & 0 & 216 & 594 & 247 & 0 & 25 & 74 & 30 & 0 & 0 & 0 & 0 \\
\hline Total undiscovered continuous resources & & & 154 & 779 & 1,965 & 884 & 17 & 91 & 246 & 106 & 0 & $\mathbf{0}$ & 1 & $\mathbf{0}$ \\
\hline
\end{tabular}

\section{References Cited}

Bottjer, Richard, 2014, Stratigraphy and oil resource potential of the Mississippian Heath Formation, Central Montana, USA [abs.], in American Association of Petroleum Geologists (AAPG), Rocky Mountain Section Meeting, Salt Lake City, Utah, September 22-24, 2013, Proceedings: American Association of Petroleum Geologists, Search and Discovery Article No. 50914.

Charpentier, R.R., and Cook, T.A., 2011, USGS methodology for assessing continuous petroleum resources: U.S. Geological Survey OpenFile Report 2011-1167, 73 p., accessed April 4, 2017, at http://pubs. usgs.gov/of/2011/1167/.

Clement, J.H., 1986, Cedar Creek-A significant paleotectonic feature of the Williston Basin, in Peterson, J.A., ed., Paleotectonics and sedimentation in the Rocky Mountain Region, United States: American Association of Petroleum Geologists Memoir 41, p. 213-240.

Derkey, P.D., Abercrombie, F.N., Vuke, S.M., and Daniel, J.A., 1985, Geology and oil shale resources of the Heath Formation, Fergus County, Montana: Montana Bureau of Mines and Geology Memoir No. 57, 100 p.

Gaswirth, S.B., Marra, K.R., Cook, T.A, Charpentier, R.R., Gautier, D.L., Higley, D.K., Klett, T.R., Lewan, M.D., Lillis, P.G., Schenk, C.J.,
Tennyson, M.E., and Whidden, K.J., 2013, Assessment of undiscovered oil resources in the Bakken and Three Forks Formations, Williston Basin Province, Montana, North Dakota, and South Dakota, 2013: U.S. Geological Survey Fact Sheet 2013-3013, 4 p., accessed April 4, 2017, at https://pubs.usgs.gov/fs/2013/3013/.

IHS Markit ${ }^{\mathrm{TM}}$, 2016, U.S. well history and production database: Englewood, Colo., IHS Markit ${ }^{\mathrm{TM}}$, accessed June 2016 at http:// www.ihsenergy.com. [Available from IHS Markit ${ }^{\mathrm{TM}}$, 15 Inverness Way East, Englewood, CO 80112.]

Maughan, E.K., 1966, Pennsylvanian and Permian paleogeography, tectonics and stratigraphy in Montana and the Dakotas, in Smith, J.R., and Weichman, B.E., Symposium on recently developed geologic principles and sedimentation of the Permo-Pennsylvanian of the Rocky Mountains, 20th Annual Conference, Casper, Wyo., August 31-September 2, 1966: Wyoming Geological Association, p. 95-108.

Maughan, E.K., and Roberts, A.E., 1967, Big Snowy and Amsden Groups and the Mississippian-Pennsylvanian boundary in Montana: United States Geological Survey Professional Paper 554-B, 27 p.

McClave, G.A., 2012, Stratigraphy and source rock analyses of the Heath Formation in Fergus, Garfield, Golden Valley, Musselshell, Petroleum, and Rosebud counties, central Montana: Colorado School of Mines, M.S. thesis, $312 \mathrm{p}$.

\section{Heath Formation Assessment Team}

Ronald M. Drake II, Christopher J. Schenk, Timothy R. Klett, Phuong A. Le, Heidi M. Leathers-Miller, Michael E. Brownfield, Thomas M. Finn, Stephanie B. Gaswirth, Kristen R. Marra, and Marilyn E. Tennyson

\section{For More Information}

Assessment results are available at the USGS Energy Resources Science Center website at https://energy.usgs.gov. 